\title{
ИЗУЧЕНИЕ КАЧЕСТВА ИНДИВИДУАЛЬНОЙ ГИГИЕНЫ ПОЛОСТИ РТА У БЕРЕМЕННЫХ ЖЕНЩИН
}

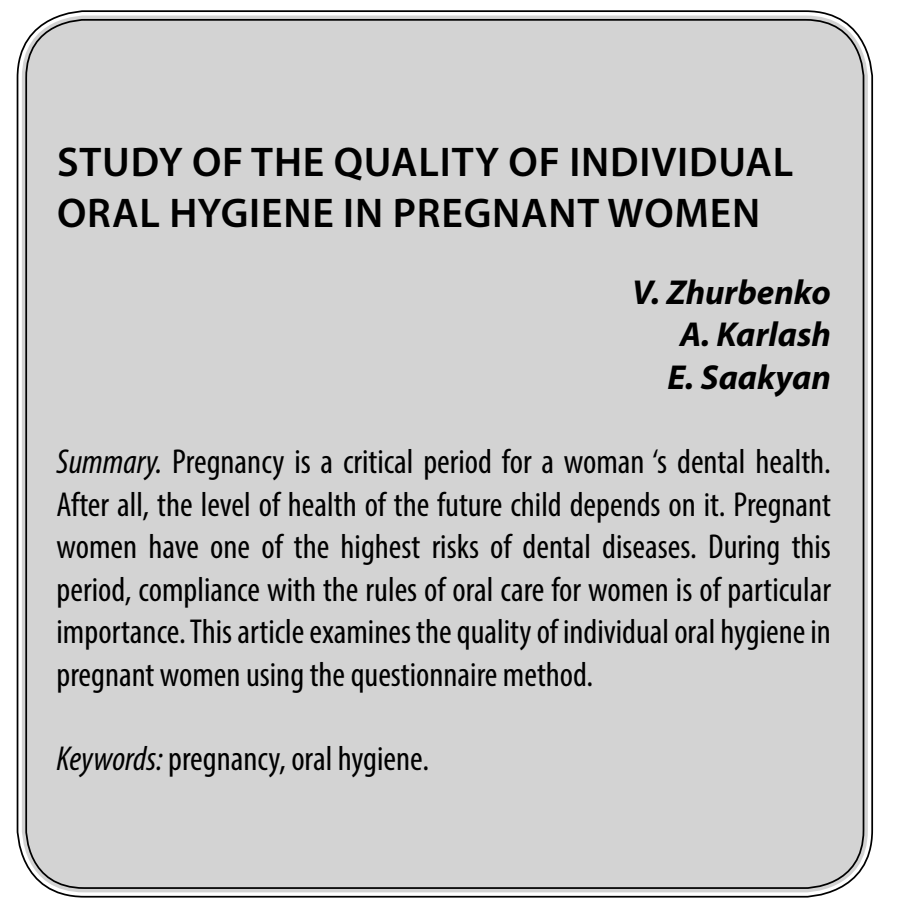

\section{Введение}

Б еременность - период жизни женщины, когда она должна уделять максимальное влияние своему здоровью, а в частности состоянию полости рта. Известно, что стоматологическое здоровье ребенка напрямую зависит от стоматологического здоровья матери.

Беременность характеризуется изменением особенностей течения многих заболеваний полости рта. Так, на ранних сроках увеличивается количество кариозных зубов, наблюдается изменение рН слюны. В этот период повышается патогенность флоры полости рта за счет усиления пролиферации условно-патогенных микроорганизмов $[1,2]$.

Как известно, неблагоприятное воздействие на антенатальное и постнатальное развитие ребенка оказывают также и тяжёлые, длительно протекающие хронические заболевания матери. Сопутствующая патология является одним из главных факторов риска в возникновении заболеваний молочных зубов у детей в возрасте до 3-х лет, так как под влиянием этого фактора нарушается формирование всех тканей будущего зуба, а также обызвествление эмали и дентина [1].

\author{
Журбенко Вероника Александровна \\ ФГБОУ ВО Курский Государственный Медицинский \\ Университет Минздрава России \\ prepvermed@mail.ru \\ Карлаш Анастасия Евгеньевна \\ К.м.н., доцент, ФГБОУ ВО Курский Государственный \\ Медицинский Университет Минздрава России \\ Саакян Эльмира Сефтеровна \\ ФГБОУ ВО Курский Государственный Медицинский \\ Университет Минздрава России
}

Аннотация. Беременность является критическим периодом для стоматологического здоровья женщины. Ведь от него зависит и уровень здоровья будущего ребенка. Беременные женщины имеют один из самых высоких рисков возникновения стоматологических заболеваний.

Особое значение приобретает в этот период соблюдение правил ухода за полостью рта женщины. В данной статье исследовано качество индивидуальной гигиены полости рта у беременных женщин методом анкетирования.

Ключевые слова: беременность, гигиена полости рта.

Качество гигиены полости рта в период течения беременности является фактором риска в этиологии кариеса и заболеваний тканей пародонта.

Цель исследования - изучение качества гигиены полости рта у беременных женщин.

Материалы и методы. Для изучения качества индивидуальной гигиены, осведомленности и просвещенности в данном вопросе было проведено анкетирование беременных женщин.

\section{Результаты исслеАования \\ и обсужАения}

Для решения поставленной цели использовали специально разработанную анкету, которая содержала вопросы, позволяющие выявить и оценить знания о правилах и средствах индивидуальной гигиены полости рта.

В анкетировании приняли участие 87 беременных женщин в возрасте от 20 до 35 лет.

Все пациентки находились на разных сроках беременности. Распределение беременных женщин в зависимости срока беременности представлено в табл. 1. 
Таблица 1. Распределение беременных по триместрам

\begin{tabular}{|l|l|l|}
\multirow{2}{*}{$\begin{array}{l}\text { триместр } \\
\text { первый триместр }\end{array}$} & \multicolumn{2}{|l|}{ Количество беременных женщин } \\
\cline { 2 - 3 } & абс. число & $\%$ \\
\hline второй триместр & 23 & 26,4 \\
\hline третий триместр & 47 & 54 \\
\hline
\end{tabular}

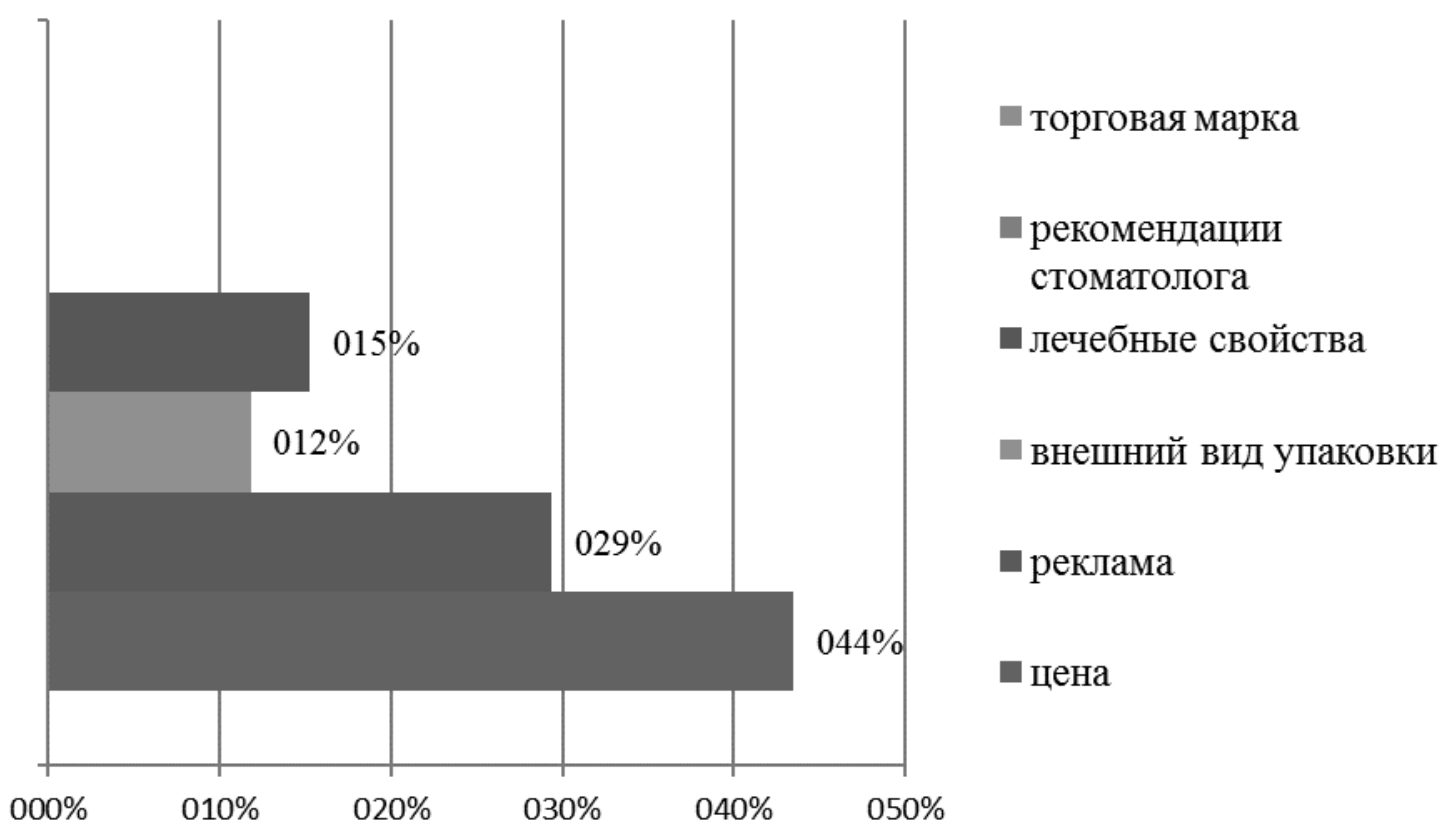

Рис. 1. Процентное распределение факторов, влияющих на выбор зубной пасты

У всех обследуемых пациентов проводили оценку гигиенического состояния полости рта с помощью индекса Федорова - Володкиной (1971 г.).

В результате исследования было выявлено, что у 63 (72,4\%) опрошенных первая беременность, у 17(19,5\%) женщин - вторая беременность, а 7 (8,1\%) беременны в третий или более раз.

Регулярная чистка зубов 2 раза в день является основой индивидуальной гигиены полости рта. Согласно результатам анкетирования, 2 раза в день чистит зубы большая часть опрошенных женщин (53), 29 человек чистит зубы ежедневно не менее 1 раза в день. Чаще 2 раз в день чистили зубы 3 женщины, а в двух случаях гигиена полости рта осуществлялась нерегулярно.

На современном рынке гигиенических товаров наблюдается большой выбор зубных щеток и паст.
Процентное распределение факторов, влияющих на выбор зубной пасты, представлено на рисунке 1. Так, для большинства женщин важна цена при покупке зубной пасты, также анкетируемые отметили рекламную информацию, внешний вид упаковки, лечебные свойства, рекомендации стоматолога, торговая марка.

Более половины анкетируемых (52\%) готовы потратить на зубную пасту до 100 рублей, 35\% покупают зубную пасту стоимостью до 200 рублей и 13\% респондентов расходуют на покупку зубной пасты свыше 200 рублей. Это говорит о том, что в основном женщины приобретают товар по относительно низким и средним ценам, и лишь небольшая часть готова приобрести товар по наиболее высоким ценам

Необходимо отметить, что 29\% женщин ценят в зубной пасте такие потребительские свойства, как отбеливающий эффект, 17\% - укрепляющий эффект, 27\% - 
защита от кровоточивости, а запах, вкус и цвет зубной пасты - 11\%, 9\% и 7\% соответственно.

Одной из основных характеристик зубной щетки является ее жесткость. Только 7 женщин использовали щетки согласно рекомендации стоматолога. Щетки со средней жесткостью использовали 70, жесткие - 7, а мягкие - 3 женщины.

Важным моментом в осуществлении гигиены полости рта является частота замены зубной щетки. При условии использования качественной зубной щетки срок ее службы составляет 1-2 мес, при более длительном употреблении теряется упругость ворсинок и соответственно снижается ее очищающая способность. Другим аспектом является высокая микробная загрязненность щетины. Результаты анкетирования показали, что большая часть опрошенных (72 человек) меняют щетки 1 раз в полгода и реже и только 15 женщин - каждые 1-2 мес. Эти данные отражают недостаточную информированность опрашиваемых в этом вопросе, влекущую за собой снижение качества чистки зубов.

В ходе исследования было выявлено, что у большинства беременных женщин индекс гигиены составил

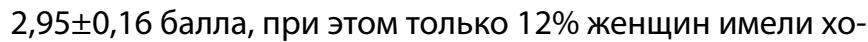
рошее состояние полости рта.

Также было отмечено, что с увеличением срока беременности увеличивается, и индекс гигиены и достигает

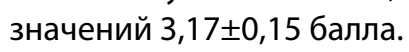

Надо отметить, что, что 24,3\% женщин отметили наличие зубного налета и кровоточивости десен, 18,5\% указали возникновение кариеса в связи с беременностью, и 16,7\% испытывают потребность в замене ранее поставленных пломб.

Необходимым условием поддержания стоматологического здоровья является регулярное посещение стоматолога. Кратность посещений определяется врачом-стоматологом, но обычно обследования проводятся 2 раза в год. В целом до беременности 1 раз в год посещали стоматологическое учреждение $46,1 \%$ обследованных женщин, 2 раза в год - 14,9\%, остальные $38 \%$ с профилактической целью не обращались.

Результат опроса показал, что большая часть опрошенных (51женщин) посещала стоматолога только при появлении неприятных ощущений.

Для осуществления гигиены полости рта на рынке гигиенических товаров имеется довольно большой выбор дополнительных предметов и средств по уходу. В связи с этим было интересно узнать, пользуются ли ими женщины, и какие из них используются наиболее часто. Результаты опроса показали, что 57 женщин не пользуется дополнительными предметами и средствами ухода за полостью рта, 30 - пользуются, при этом наиболее часто применяются зубочистки и зубные нити (флоссы), реже - эликсиры.

После проведенного анкетирования всем пациенткам было проведено индивидуальное обучение гигиене полости рта с контролем качества гигиенической очистки зубов.

\section{Выво $\triangle \mathrm{b}$}

Состояние стоматологического здоровья беременной женщины влияет на зубочелюстную систему ребенка. Таким образом, соблюдая правила индивидуальной гигиены полости рта, женщина заботится о здоровье будущего ребенка. Однако, несмотря на множество представленных средств для гигиены полости рта, большинство беременных женщин не уделяют должного внимания знаниям о них. В этой связи, главную роль в обучении должны играть врачи-стоматологи [3].

\section{ЛИТЕРАТУРА}

1. Добровольская, П. Э. Профилактика стоматологических заболеваний в современном обществе / П. Э. Добровольская, А. С. Ковалёва // Международный журнал экспериментального образования. — 2015. — № 11-6. — С. 840-847.

2. Журбенко, В. А. Гигиена полости рта как метод профилактики заболеваний пародонта / В. А. Журбенко, Э.С. Саакян // Актуальные проблемы и достижения в медицине. Сборник научных трудов по итогам международной научно-практической конференции. — № 2. — Самара.— 2015 г. - С. $152-154$ с.

3. Профилактика стоматологических заболеваний у беременных — основа стоматологического здоровья детей раннего возраста / В. А. Журбенко, Э. С. Саакян, Д. С. Тишков // Международный журнал экспериментального образования._ 2015.— № 3-5.— С. 582-583.

(с) Журбенко Вероника Александровна ( prepvermed@mail.ru),

Карлаш Анастасия Евгеньевна, Саакян Эльмира Сефтеровна.

Журнал «Современная наука: актуальные проблемы теории и практики» 